\title{
進行性膀胱癌に対する治療経験
}

一とくに抗腫瘍剤の内腸骨動脈内注入療法について一

\begin{tabular}{|c|c|c|c|c|c|}
\hline \multirow{3}{*}{$\begin{array}{c}\text { 関東派信病院泌尿器科 } \\
\text { (部長：小川秀弥) }\end{array}$} & 河 & 野 & & 信 & 一 \\
\hline & 久 & 保 & 田 & 正 & \\
\hline & 田 & 中 & & 求 & \\
\hline & 小 & 川 & & 秀 & \\
\hline
\end{tabular}

\section{EXPERIENCE OF INTRA-ARTERIAL CHENOTHERAPY FOR ADVANCED BLADDER CANCER WITH ANTITUMOR AGENTS}

\author{
Shinichi Kawano, Masamitsu Kubota, Kyuhei Tanaka and Hideya Ogawa \\ Department of Urology, Kantohteishin Hospital, Tokyo, Japan
}

(Chief: H. Ogawa)

Fifteen patients were treated by infusion of antitumor agents via the internal iliac artery. Of these patients, twelve patients had advanced bladder cancer and other three cases included the pelvic invasion from a cervical cancer, from a uterine sarcoma and from a rectal cancer.

Drugs of arterial infusion were Mitomycin C, 5-Fluorouracil, Carbazilquinone and Cisdiamminedichloroplatinum.

Six cases in the all were combined arterial embolization for purpose of antitumor and hemostasis. And other combination treatments were done before and after arterial infusion therapy. Those included surgery, radiation, hyperthermia and intravesical instillation with antitumor agents.

As a result, this arterial infusion treatment was suitable, safety and effective method in aim to antitumor and hemostasis for advanced bladder cancer.

要旨：著者らは, 膀胼進行癌12例と子宮頝癌の骨盤内浸潤, 骨盤腔内 endolymphatic stromal sarcoma, 直腸癌の術後再発各 1 例, 計15例の骨盤内浸潤癌患者に対して, 抗腫瘍剂の内腸骨動脈内注入療法を施 行した。

動脈内注入薬としては, Mitomycin C (MNC), 5-Flourouracil (5-FU), Carbazilquinone (CQ), Cisplatinum (CDDP)などを使用した。15例のうち 6 例には抗腫瘍効果と止血効果を目的として embolization を行った。その他の併用治療としては手術, 放射線療法, 温水療法や膀脱内注入療法などを施行し た。

これらの症例の抗腫瘍効果，止血効果および副作用を検討した結果，進行癌を対象とした治療として 本法は，安全かつ有効な手段であると思われた。

緒言

近年種々の有効な癌化学療法剤が数多く開発され， 癌化学療法もそれなりの進歩をとげつつある。しかし ながら膀胱末期癌や近接臟器癌の膀胱浸潤に対する全 身的・系統的化学療法は, 諸家の報告を通覧するに期 待されるほどの好成績は認められない。

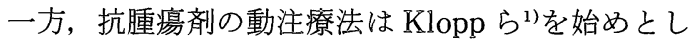
た多くの報告がみられ，膀脱癌に対する内腸骨動脈内
注入療法は, 手術不能な症例や高齢者などに用いられ 最近はかなり良好な成績が得られている233)。

著者らは, 膀胱癌を主とする骨盤腔内進行癌15例に 本法を行い, 抗腫瘍効果, 止血効果, 延命その他の効 果および副作用などについて検討を行った結果，良好 な成績と若干の知見を得たので報告する。な敃代表的 有効例 3 例についても附記する。 
Fig. 1 Method of intra-arterial infusion of MMC (40mg/40ml)

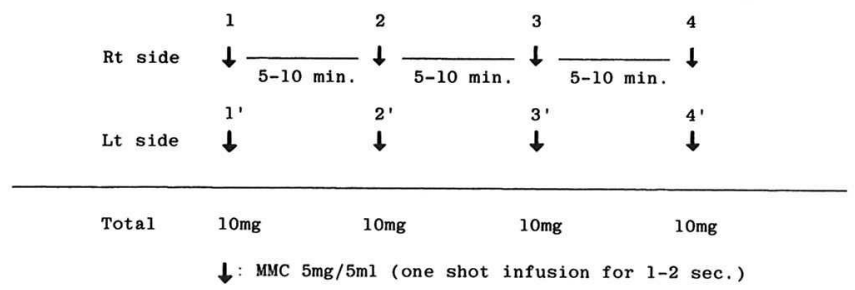

対象および治療方法

症例は1975年から1982年までの 8 年間に関東逓信病 院泌尿器科に㧍いて, 抗腫瘍剂の内腸骨動脈内注入療 法を施行した15例（男子 9 例, 女子 6 例）である。 こ れらの症例のうち 6 例には抗腫瘍拉よび止血効果を目 的とした embolization を併用した。膀胱癌は12例, そ の他 3 例は子宮頝癌の骨盤内浸潤, 骨盤腔内 endolymphatic stromal sarcoma, 再発性直腸癌の膀胱浸潤抒 よび放射線治療による膀脱出血合併症例であった。

動注方法は, ほとんどが Seldinger 法に基づくが, 2 例には開腹および上烠動脈よりの持続注入用カテーテ ルを留置した4). 著者らは，原則としてカテーテルを Seldinger 法により両側内腸骨動脈の上臀動脈を越兄 た部位に留置した。

薬剂は種々の理由から主として MMCを使用した。 予め MMC 40mg を40ml の生食に溶解し, 左右各 20 mg を Fig. 1 の如く, 両側に各 $5 \mathrm{mg} / 5 \mathrm{ml}$ を $1 \sim 2$ 秒で 注入, 5 10分毎にこの注入をくり返す方法 (one shot 変法）で行った. さらに有効例に対しては, 本法を 6 カ月毎に繰り返した。その他5-FU, CQ, CDDP も使用 した。

またこれらの症例のらち 6 例には, 抗腫瘍および止 血効果を目的とした embolizationを併用した。 embolization の材料は, ゼルフォーム, 金属コイルを用い た.

その他の併用治療としては TUR などの手術療法, 全身への化学療法, 膀脱腔内注入療法, 温水療法打上 び放射線療法などを, 本法の前後に施行した。

効果判定は触診, 膀胱鏡, 膀胱造影, 骨盤内動脈撮 影などにより行い，小山・斉藤班基準5) も参考にした。 なお primary effect としては, 腫瘍の完全に消失した ものを $\mathrm{CR}$, 明らかに縮小したものを $\mathrm{PR}$ ，わずかに縮 小・不変・増大を NR とした。

症 例

個々の症例については Table 1 に示した通りであ
Fig. 2 (Case 1) 動注前 CG. 腫瘍は膀胱内全体を 占る.

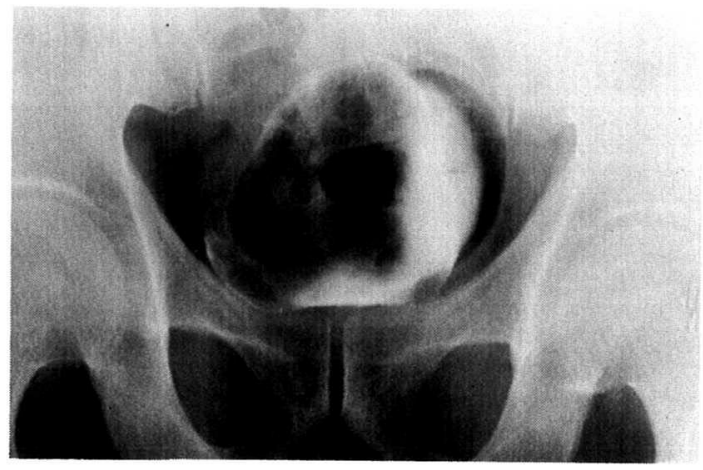

Fig. 3 （Case 2）動注後 CG. 腫瘍の著明な縮小をみ た.

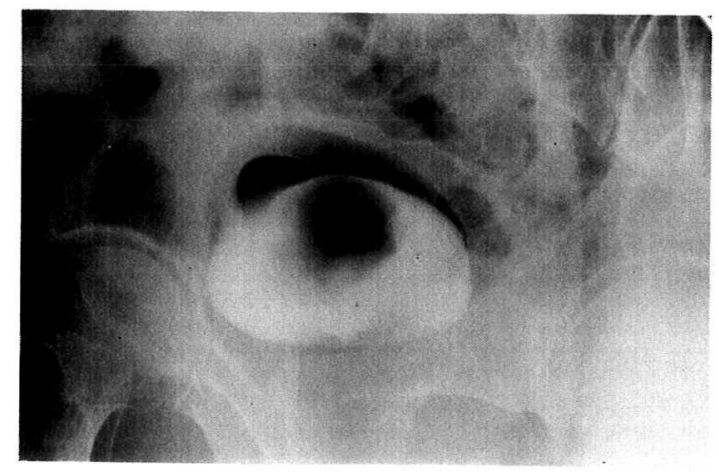

るが，特に著明な primary effect の認められた 3 症例 について簡単に述べる。

Case $1: 59$ 歳, 男性.

前立腺浸潤を伴ら膀胱内全体を占る膀胱移行上皮 癌。

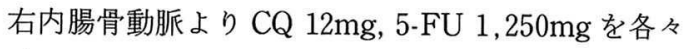
3 時間にわたり間歇的持続注入を施行した結果，膀脱 鏡，膀胱造影にて腫瘍の著明な縮小を認めた（Fig. 2, $3)$. 
Table 1 Intra-arterial chemotherapy for advanced bladdeder tumor

\begin{tabular}{|c|c|c|c|c|c|c|c|c|c|c|}
\hline \multirow[b]{2}{*}{ Case } & \multirow[b]{2}{*}{ Age } & \multirow[b]{2}{*}{ Sex } & \multirow{2}{*}{$\begin{array}{l}\text { Tumor } \\
\text { Diam. (cm) } \\
\text { Stage. Grade }\end{array}$} & \multirow{2}{*}{$\begin{array}{l}\text { Int. art. Inf. } \\
\text { Drug.Dose (mg) }\end{array}$} & \multirow{2}{*}{$\begin{array}{l}\text { Embo- } \\
\text { lization }\end{array}$} & \multicolumn{2}{|c|}{ Effects } & \multirow[b]{2}{*}{ Side effects } & \multirow{2}{*}{$\begin{array}{l}\text { Combination } \\
\text { therapy }\end{array}$} & \multirow[b]{2}{*}{ Prognosis } \\
\hline & & & & & & \begin{tabular}{|l|} 
(for \\
tumor) \\
\end{tabular} & \begin{tabular}{|l|} 
(for \\
bleeding)
\end{tabular} & & & \\
\hline 1 & 59 & M & $\begin{array}{l}\text { TCC } \\
5< \\
\mathrm{T}_{4}, \mathrm{GIII}\end{array}$ & $\begin{array}{l}\text { CQ12, 5FU1250 } \\
\text { rt-only }\end{array}$ & - & PR $1 / 10$ & / & $\begin{array}{l}\text { leukopenia } \\
\text { thrombocytopenia } \\
\text { anemia }\end{array}$ & $\begin{array}{l}\text { IcI }(\mathrm{MMC}, 5 \mathrm{FU}) \\
\mathrm{Ra} 8000 \mathrm{r}\end{array}$ & died after $48 \mathrm{M}$ \\
\hline 2 & 57 & M & $\begin{array}{l}\text { TCC } \\
5< \\
\mathrm{T}_{4}, \mathrm{GIII}\end{array}$ & $\begin{array}{l}\text { MMC40, 5FU500 } \\
\text { rt-only }\end{array}$ & - & PR $1 / 3$ & / & anemia & $\begin{array}{l}\text { IcI }(C Q, 5 F U, M M C) \\
\operatorname{Ra} 6000 \mathrm{r}\end{array}$ & died after $36 \mathrm{M}$ \\
\hline 3 & 64 & $\mathrm{~F}$ & $\begin{array}{l}\text { TCC } \\
2-5 \\
\mathrm{~T}_{3}, \mathrm{GII}\end{array}$ & $\begin{array}{l}\text { MMC40 } \\
\mathrm{rt}-20 \\
\text { lt-20 }\end{array}$ & $\begin{array}{c}+ \\
(\mathrm{rt})\end{array}$ & PR $1 / 2$ & $\mathrm{CR}$ & - & $\begin{array}{l}\text { IcI (MMC, CQ) } \\
\text { TUR } \\
\text { Ra 2500r }\end{array}$ & alive after $45 \mathrm{M}$ \\
\hline 4 & 74 & $\mathrm{~F}$ & $\begin{array}{l}\text { TCC }\left(^{*}\right) \\
5< \\
\mathrm{T}_{3}, \text { GII }\end{array}$ & $\begin{array}{l}\text { MMC44 } \\
\text { rt-19 } \\
\text { lt-25 }\end{array}$ & $\begin{array}{c}+ \\
(1 \mathrm{t})\end{array}$ & NR & $\mathrm{CR}$ & $\begin{array}{l}\text { leukopenia } \\
\text { anemia }\end{array}$ & IcI $(\mathrm{MMC})$ & died after $9 \mathrm{M}$ \\
\hline 5 & 49 & $\mathrm{~F}$ & $\begin{array}{l}\text { TCC (*) } \\
2> \\
\mathrm{T}_{2}, \mathrm{GII}\end{array}$ & $\begin{array}{l}\text { CDDP25 } \\
\mathrm{rt}-12.5 \\
\mathrm{lt}-12.5\end{array}$ & $\begin{array}{c}+ \\
\text { (bil) }\end{array}$ & PR $1 / 10$ & $\mathrm{CR}$ & gluteal pain & $\begin{array}{l}\text { IcI }(M M C, C Q) \\
\text { TUR }\end{array}$ & alive after $99 \mathrm{M}$ \\
\hline 6 & 68 & M & $\begin{array}{l}\text { TCC } \\
5< \\
\mathrm{T}_{3}, \text { GIII }\end{array}$ & $\begin{array}{l}\mathrm{MMC} 40 \\
\mathrm{rt}-20 \\
\text { lt-20 }\end{array}$ & - & $\begin{array}{l}\text { NR } \\
\text { PR }\end{array}$ & l & cystitis & IcI (CDDP) & unknown \\
\hline 7 & 58 & M & $\begin{array}{l}\text { TCC }\left(^{*}\right) \\
2> \\
\mathrm{T}_{4}, \mathrm{GIII}\end{array}$ & $\begin{array}{cr}\text { MMC40, } & \text { FU500 } \\
\text { rt-20, } & 250 \\
\text { lt-20, } & 250\end{array}$ & - & PR & / & anemia & IcI (MMC, CQ) & died after $6 \mathrm{M}$ \\
\hline 8 & 53 & $\mathrm{~F}$ & $\begin{array}{l}\text { TCC }\left(^{*}\right) \\
5< \\
\mathrm{T}_{4}, \text { GIII }\end{array}$ & $\begin{array}{rr}\text { MMC40, } & 5 \mathrm{FU} 2000 \\
\mathrm{rt}-20, & 1000 \\
\mathrm{lt}-20, & 1000\end{array}$ & - & PR $1 / 2$ & / & - & IcI (CQ) & died after $9 \mathrm{M}$ \\
\hline 9 & 69 & M & $\begin{array}{l}\mathrm{TCC}\left({ }^{*}\right) \\
2> \\
\mathrm{T}_{4}, \mathrm{GIII}\end{array}$ & $\begin{array}{l}\mathrm{MMC} 40 \\
\mathrm{rt}-20 \\
\mathrm{lt}-20\end{array}$ & - & NR & I & $\begin{array}{l}\text { leukopenia } \\
\text { anemia }\end{array}$ & $\begin{array}{l}\text { IcI }(C Q, 5 F U) \\
\text { TUR, HTT } \\
\text { Ra 4000r }\end{array}$ & died after $8 \mathrm{M}$ \\
\hline 10 & 46 & M & $\begin{array}{l}\text { TCC } \\
5< \\
T_{4}, \text { GIII }\end{array}$ & $\begin{array}{l}\text { MMC40 } \\
\mathrm{rt}-20 \\
\text { lt-20 }\end{array}$ & - & NR & / & - & $\begin{array}{l}\text { IcI }(M M C) \\
\text { Ra 3000r }\end{array}$ & died after $39 \mathrm{M}$ \\
\hline 11 & 71 & M & $\begin{array}{l}\text { TCC } \\
5< \\
\mathrm{T}_{4}, \text { GIII }\end{array}$ & $\begin{array}{l}\text { MMC40 } \\
\text { rt-only }\end{array}$ & $\begin{array}{c}+ \\
\text { (bil) }\end{array}$ & NR & PR & gluteal necrosis & $\begin{array}{l}\text { IcI (MMC) } \\
\text { HTT }\end{array}$ & died after $9 \mathrm{M}$ \\
\hline 12 & 58 & M & $\begin{array}{l}\text { TCC } \\
2-5 \\
\mathrm{~T}_{4}, \mathrm{GIII}\end{array}$ & $\begin{array}{l}\text { MMC30 } \\
\text { rt-only }\end{array}$ & - & PR $1 / 2$ & / & gluteal pain & $\begin{array}{l}\text { IcI (MMC) } \\
\text { TUR }\end{array}$ & alive after $47 \mathrm{M}$ \\
\hline 13 & 54 & $\mathrm{M}$ & $\begin{array}{c}\text { Rectal cancer } \\
\mathrm{T}_{4}\end{array}$ & / & $\begin{array}{c}+ \\
\text { (bil) }\end{array}$ & / & PR & - & - & died after $12 \mathrm{M}$ \\
\hline 14 & 60 & $\mathrm{~F}$ & $\begin{array}{l}\text { Uterus cancer } \\
\mathrm{T}_{4}\end{array}$ & $\begin{array}{l}\text { MMC40 } \\
\text { rt }-20 \\
\text { lt-20 }\end{array}$ & $\begin{array}{c}+ \\
\text { (bil) }\end{array}$ & I & $\mathrm{CR}$ & anemia & - & alive after $38 \mathrm{M}$ \\
\hline 15 & 40 & $\mathrm{~F}$ & $\begin{array}{l}\text { Uterus sarcoma } \\
\mathrm{T}_{4}\end{array}$ & $\begin{array}{cc}\text { MMC40, } & \text { CDDP175 } \\
\text { rt-30, } & 115 \\
\text { lt-10, } & 60\end{array}$ & - & PR $1 / 3$ & l & $\begin{array}{l}\text { leukopenia } \\
\text { thrombocytopenia } \\
\text { gluteal pain } \\
\text { alopecia }\end{array}$ & Progest. & alive after $71 \mathrm{M}$ \\
\hline
\end{tabular}

(*) : multiple tumor

$\mathrm{Ra}:$ Radiation

TUR : Transurethral Resection
IcI : Inrtacavitary Instillation

HTT : Hyperthermia Therapy

Progest. : Progesterone 
Fig. 4 （Case 2）治療前 CG. 右側半分以上を占る腫 瘍.

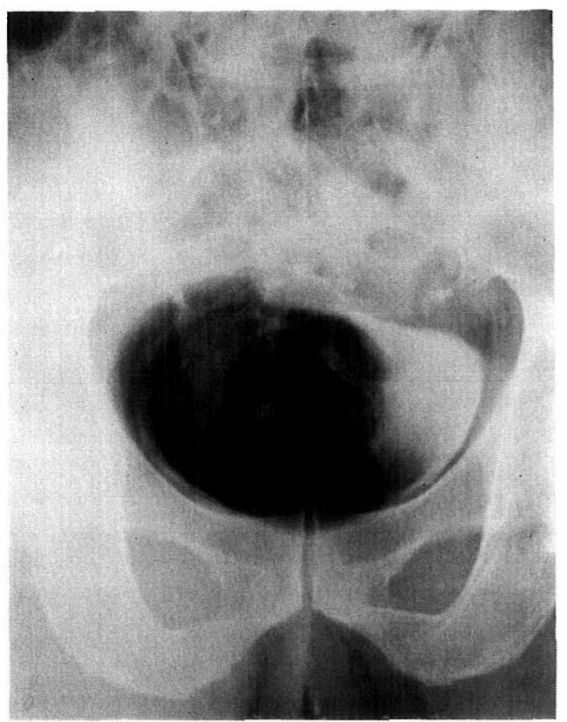

Case $2: 57$ 歳, 男性.

膀胱の右側半分以上を占め, 直腸に浸潤を呈する Grade III の膀胼移行上皮癌.

右内腸骨動脈より $\mathrm{MMC} 40 \mathrm{mg}$ と5-FU 500 $\mathrm{mg}$ の注 入を行った。 その後 $\mathrm{MMC}, \mathrm{CQ}, 5-\mathrm{FU}$ の膀胼内注入療 法,さらに6,000rads の放射線療法を併用した。

腫瘍は 3 分の 1 の以下に縮小し 2 年間はその増大を 認めなかった（Fig. 4, 5).

Case 15：42歳, 女性.

40歳時に endolymphatic stromal scrcoma にて子 宮・右卵巣・卵管を剔除するも骨盤腔内に再発し，尿 路浸潤をきたした。腫瘍は骨盤内に小児頭大に触知， 右側は腎機能はなく, 左側に水腎症が著明であった (Fig. 6).

約 3 年間にわたり, Seldinger 法に基づき両側内腸 骨動脈より MMC 40mg を 1 回，CDDP 25-50mg を 3 回（いずれも one shot 变法）それぞれ約 6 力月毎に動 注を行った結果, 腹痛・血性帯下の消失, 腫瘍の著明 な縮小と両腎機能の改善をみた（Fig. 7).ささらに上慰 動脈上り右内腸骨動脈へ持続注入用の catheterizationを行いCDDP 25mg (one shot) を 3 カ月毎に 2 回注入し経過良好である。

\section{治療効果}

1. 抗腫瘍効果

完全に腫瘍を消失せしめたものはなかったが，明ら
Fig. 5 （Case 2）治療後 CG. 1/3以下に縮小した腫 痬.

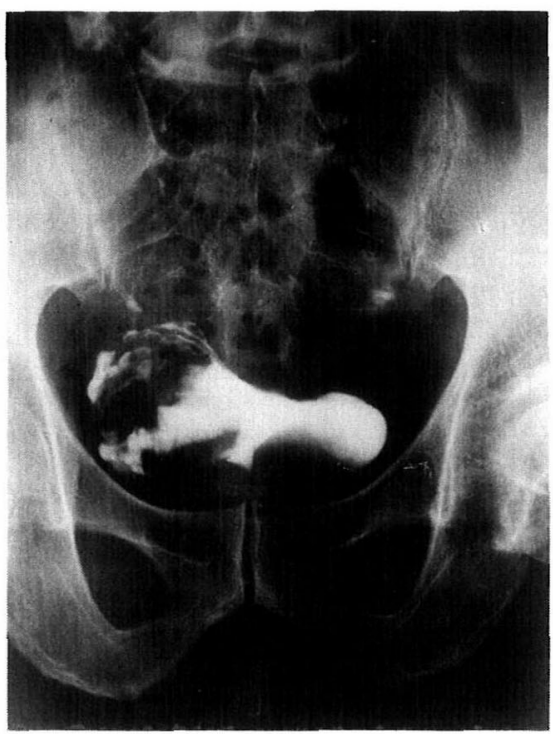

Fig. 6 (Case 15) 上) IVP : 右側は無機能腎, 左側 は水腎症が著明.下) $\mathrm{AG}$ ：骨盤腔内に大きな tumor stain.
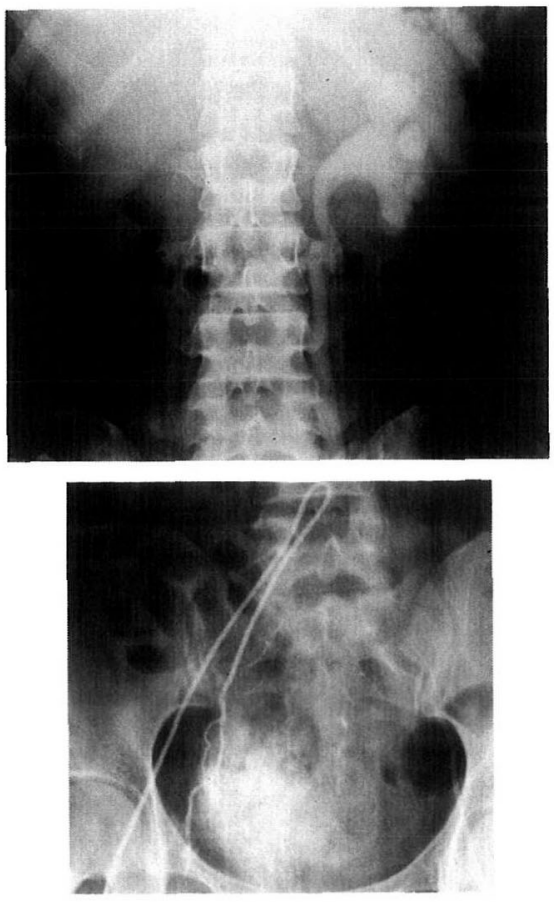

かに縮小したものは13例中 8 例に認められ，約 $60 \%$ に 有効であった（Table 2). 
Fig. 7 (Case 15）上) IVP : 左側の水腎症の改善, 右側の造影剤の排泄を認める。下） 3 回動注後の $\mathrm{AG}$ ：著明な改善をみる.

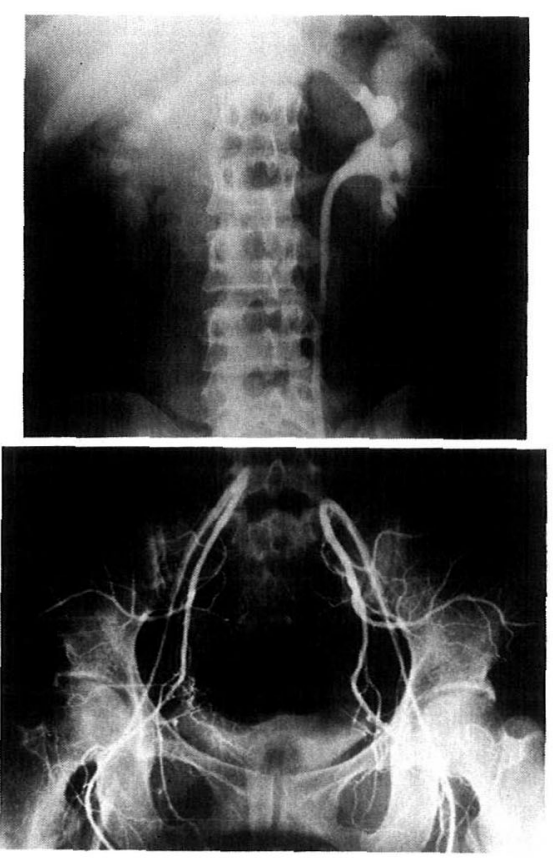

また明らかに延命効果の認められた症例は，14例中 9 例（1 例は予後不明)，約64\%であった (Table 1).

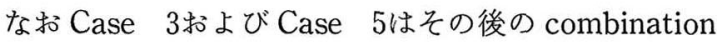
therapy などにより現在 tumor free, case 12，14，15は その後の intra-arterial chemotherapy p combination therapyにより tumor と生体とが共存共栄の状 態にある。

2. 止血効果

各種止血剂の全身投与では全く改善のみられなかっ た高度で頑固な膀胱出血に対して， CR 約 $67 \%, \mathrm{PR}$ 約 33\% と非常に有効であった（Table 3）.

\section{副 作 用}

副作用としては，全身的なものは造血機能に関する ものがほとんどであったが重症例はなく，いずれも動 脈注入後数力月で回復した。 また 1 例に脱毛が認めら れたが，数カ月で回復した。

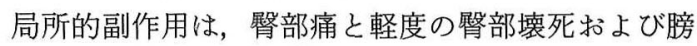
胱刺激症状が認められたのみで重篤なるのはなからた (Table 4). 一方副作用の全くみられなかった症例も 15例中 4 例確認されている (Table 1).

$$
\text { 考 案 }
$$

膀胖浸潤癌に対する抗腫瘍剤の動脈内注入療法は,
Table 2. Anticancer effects by intra-arterial chemotherapy ( 13 cases)

\begin{tabular}{c|c|c}
\hline Effect & No. of Pat. & (\%) \\
\hline CR & 0 & 0 \\
PR & 8 & 62 \\
NR & 5 & 38 \\
\hline
\end{tabular}

Table 3. Effects for bleeding (6 cases)

\begin{tabular}{c|c|c}
\hline Effect & No. of Pat. & (\%) \\
\hline CR & 4 & 67 \\
PR & 2 & 33 \\
NR & 0 & 0 \\
\hline
\end{tabular}

Table 4. Systemic and Local side effects in 15 cases

\begin{tabular}{l|c}
\hline \multicolumn{1}{c|}{ Side effect } & No. of Pat. \\
\hline Systemic & \\
Leukopenia & 4 \\
Anemia & 6 \\
Thrombocytopenia & 2 \\
Alopecia & 1 \\
Local & 3 \\
Gluteal pain & 2 \\
Gluteal necrosis (slightly) & 1 \\
Cystitis & \\
\hline
\end{tabular}

抗腫瘍剤の腫瘍組織内濃度をできるだけ高くし，他の 健常組織に対する副作用を最少に止めることが理想的 であることは諸家の認めるところであろう。

1. 注入方法について

内外諸家の文献を通覽するに注入方法としては Seldinger 法による A. iliaca int. あるいはさらに末梢側 への superselective catheterization，手術的に支配動 脈内に catheterを留置してこれから持続的あるいは 間歇的に注入する方法, 上篮動脈より catheterを A. iliaca int. に留置する方法, さらに腫瘍領域に, A-V シャントを作製し局所灌流を行う方法など種々の試み がなされている。

著者らは, 手技が最も簡単で安全かつ確実な Seldinger 法による A. iliaca int. への動注を主として施行し た。

注入薬剤は主として MMC 40mg であるが，これは 服部ら ${ }^{6}$ の本剂大量 one shot 静注法で副作用も少なく 極めて安全な量であることが確認されていることから 
Table 5. Effects of inta-arterial chemotherapy for advanced bladder tumors

\begin{tabular}{c|c|ccc|c|c}
\hline $\begin{array}{c}\text { Author and } \\
\text { year }\end{array}$ & $\begin{array}{c}\text { Number } \\
\text { of patients }\end{array}$ & \multicolumn{2}{|c|}{$\begin{array}{c}\text { CR PR } \\
\text { (or slight dec.) }\end{array}$} & $\begin{array}{c}\text { Antitumor } \\
\text { agents }\end{array}$ & Total dose(mg) \\
\hline $\begin{array}{c}\text { Hayahara et al. } \\
1978\end{array}$ & 5 & 0 & 2 & 3 & ADM & $100-200$ \\
\hline $\begin{array}{c}\text { Sakamoto, Ogata } \\
1981\end{array}$ & 17 & 1 & 7 & 9 & MMC & $60-70$ \\
\hline $\begin{array}{c}\text { Tanaka et al. } \\
1982\end{array}$ & 4 & 0 & 4 & 0 & CDDP & unknown \\
\hline $\begin{array}{c}\text { Wallace et al. } \\
1982\end{array}$ & 15 & 6 & 3 & 6 & CDDP & $240-740 \mathrm{mg} / \mathrm{m}^{2}$ \\
\hline $\begin{array}{c}\text { Kawano et al. } \\
1982\end{array}$ & 13 & 0 & 8 & 5 & MMC & 40 \\
\hline
\end{tabular}

Table 6. Prognosis after IAI with MMC for bladder tumors (5-year survival)

\begin{tabular}{l|c|c}
\hline \multicolumn{1}{c|}{ Author } & Sakamoto et al. & Kawano et al. \\
\hline Prognosis/Tumor stage & $\mathrm{T}_{2}-\mathrm{T}_{4}$ & $\mathrm{~T}_{3}-\mathrm{T}_{4}$ \\
\hline alive without tumor. & 6 & $1(1)$ \\
alive with tumor. & 2 & $1(2)$ \\
died of extension of tumor. & 5 & 8 \\
died of side effects of treatment. & 2 & 0 \\
died of other causes. & 2 & 0 \\
\hline Total & 17 & $10(3)$ \\
\hline
\end{tabular}

( ) : 38-47 months

IAI : intra-arterial infusion

1 回量 $40 \mathrm{mg}$ とした.

動注方法は単なる one shotでは血中および腫瘍組 織内濃度は，高濃度が得られるが作用時間が短か過ぎ る欠点がある。

一方持続注入では, 作用時間は長いが MMC の腫瘍 完全発育阻止濃度とされている $10 \mathrm{mcg} / \mathrm{ml}$ を得ること は極めて困難であり，抗腫瘍効果を得るためには overdose になりがちで side-effect が多くみられるよ らになってくる。

著者らは本剤による intracavital instillation おょ び intra-arterial infusion for renal cell carcinoma の 経験78) から MMC の膀胱腫瘍組織に組織形態学的効 果や本剂の正常膀胱組織と腫瘍組織とに対する差異な どを考慮し，副作用を最少にとどめ抗腫瘍効果をでき る限り高め,さらに primary effect だけでなく有効例 に対しては 6 カ月毎に本法を繰り返し行らことにより tumor と生体とが共存共栄の状態を長期に渡り継続 (Case 12，14，15）できるように Fig。1の如き注入方 法を試み，ほぼ満足すべき結果が得られてきると考え ている。

\section{2。治療効果について}

primary effectは Table 2 に示した如く，CR はな く PR 8, NR 5 (有効率約60\%) であったが，Case 3 およびCase 5はその後の combination therapyによ り45掞よび99カ月後の現在 tumor free である。

intra-arterial chemotherapy に関する最近の報告 の中から high stage ( $\mathrm{T}_{3}$ または $\mathrm{B}_{2}$ 以上) の bladder tumorを対照としたもののみを pick up してみると Table 5 の如くである。

注入薬剤・量・方法および判定基準などがそれぞれ 異なって扣り，安易な比較はできないが total dose が 少量の割には諸家の成績とほぼ同程度の primary effect が得られたと思われる。

prognosisについてはさらに複雑な要因により諸家 との比較が困難ではあるが Wallace ら²)の「The survival lengths ranged from 26 104 weeks, with a median survival length thus far, of 52 weeks.」との 比較では著者らはそれぞれ $24 \sim 496$ 週，平均142週とな り，かなり良好である。

酒本ら ${ }^{9} の 5$ 年予後との比較では Table 6 の如くで 
あり, 酒本らの症例のなかに $\mathrm{T}_{2}$ のものが何例あるか不 明ではあるが，著者らのものよりさらにすぐれている 上らに思われる。な打（）内は $38 ， 45 ， 47$ 月生存 例である effect for bleeding に関する embolization

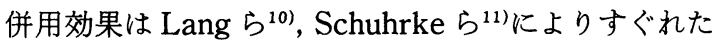
止血効果が報告されているが, 最近本邦でも難治性膀 脱出血に対する embolization の有効性が学会報告な どで散見されるよらになってきた。

著者らは今回の難治性膀腅出血に対する内腸骨動脈 embolization に先だって, 1979年に放射線性膀脱炎に よる難治性出血例に開腹, 両側内腸骨動脈結禁術を行 い止血に成功しており, その後も同様の 2 症例に対し て同様の結禁術を試みいずれも完全止血し得た経験か ら今回患者にとって最も riskの少ない Seldinger 法 による止血を試みた次第である.

今回著者らは1981年 3 月から1982年10月までの約 1 年半の間に膀脱 tamponade を繰り返す 4 例の膀脱末 期癌と直腸拈よび子宮より膀胱への浸潤癌各 1 例に本 法を施行したが Table 3 の如くほぼ満足すべき結果 を得ることができた。これらの症例のうち PR が 2 例 あるが，これは 1 例は膀胼癌の前立腺浸潤例であり他 の 1 例は直腸癌の膀胱浸潤例であるところからその血 行動態からみて当然の結果であるといえょう.

一方 embolization による抗腫瘍効果については, 本 法単独による検討を行っていないので言及できない が, 現時点では著者らは膀胱末期癌に対しては, 抗腫 瘍剤の動注が主たるものであり, embolizationはこの

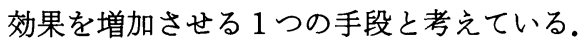

3. 副作用について

抗腫瘍剂の内腸骨動脈内注入療法による副作用は systemic には程度の差はあるが系統的投与法と何ら 変るところはない，従って本法を行う場合には，あく までも ovardose にならないよらに注意すべきであ り, primary effectにとらわれ過ぎる余り担癌生体が side reactionのために不可逆的あるいはそれに近い damage を受ける程の投与総量は厳につつしむべきで あると考えている。

著者らの症例に括ける systemic side-effectは, Table 4 の如くであるが重篤なるのはなくいずれも比 較的速やかに回復している. 軽微な systemic sideeffect, $3 \sim 6$ 力月毎の繰り返しの動注療法が可能と いうことから考劣ると, この MMCに関する限りは 1 回投与総量は $40 \mathrm{mg}$ 前後, $60 \mathrm{mg}$ 以下が適当ではないか と思われる。
著者らの15症例における local side-effect は, Table 4 に示したと拈りで発現頻度は低くその程度も軽度で あった。

対献的には腎部および会陰部壊死, 膀胼穿孔, 皮庿 感覚異常, 神経障害による下肢の麻㾝や疼痛, 膀朕炎 様症状などが報告されている。

これら局所的副作用を軽減させるには以下に記する 点に特に留意すべきであると考えている。

a. 投与総量が overdose とならないこと. 投与薬剤 にもよるが, MMCの場合は 1 側 1 回（1クール） $10 \sim 30 \mathrm{mg}$, 両側総量 $20 \sim 60 \mathrm{mg}$ 程度が適当ではないか と思われる。

b. 血管カテーテルの先端が上剧動脈を越えている こと、これは殽部壊死のみならず，腫瘍内濃度をより 高めるためにも必要と思われる.

c. 上慰動脈を越えることのみに気を取られている と血管カテーテル先端が内陰部動脈・閉鎖動脈に多量 に薬剤が注入される位置に固定され，会陰部や肛囲の 壊死をきたすことがあり特に注意を要する。この際患 者側の条件がゆるせば少量の epinephrin を併用する とより有効である。

以上の 3 点に留意すれば, 本動注療法は比較的容易 で安全な膀胼浸潤癌に対する最も有効な治療法である と考学られる。

embolizationによる副作用は発熱や局所痛などが あるが，腎動脈栓塞術に比して軽微でありほとんど問 題となるものはないと思われる。これは骨盤腔内に括 ける血行動態は非常に複雑であり，さきにも述べたが 著者らが 3 例の難治性膀腅出血に対して, 経後腹膜的 に両側内腸骨動脈結禁術を施行した際にその末梢側断 端からも拍動性出血が認められたことから, 内腸骨動 脈結禁術や栓塞術に際しては, 膀膫穿孔, 支配領域の 壊死, 皮膚知覚異常, 神経障害などは考吕る必要はな いと考えている.

したがって A. iliaca int. の embolization 単独の場 合は上慰動脈, 内陰部動脈, 閉鎖動脈など全く意に介 することなく行い得るが, むしろこの embolizationに より起こる逆行性による side reaction としての腫瘍 の血行性転移対策を有効な化学療法を併用するなどし て十分考慮すべきであろう。

\section{まとめ}

1. 12例の advanced bladder tumor と各 1 例の膀 胼へ浸潤した rectal cancer, uterine cancer, uterine sarcoma 計15例の advanced pelvic tumorに対して 
抗腫瘍剂（主としてMMC）の内腸骨動脈内注入療法 （one shot 变法）を施行し以下の如き良好な治療効果 を得た。

a） primary effect として腫瘍の消失したものはな かったが，著明に縮小したもの（PR）8例，わずかに 縮小・不変または増大 (NR) 5 例, 不明 1 例であった。

b) 動注後種々の combination therapyを行い, 38 99 月間の予後観察では tumor free で生存 2 例, 担癌者として生存 3 例, 腫瘍死 9 例, 不明 1 例であっ た。

2. 難治性膀胱出血 6 例に対して内腸骨動脈栓塞術 を併用し，完全に止血し得たもの 4 例，完全ではない が，ほぼ満足すべき止血効果を認められたもの 2 例で あった。

3. 抗腫瘍剂の内腸骨動脈注入療法に打ける注入方 法, 注入薬剤の総量などについて効果, 副作用両面か ら若干の考察を加えると共に内腸骨動脈栓塞術につい ての見解も述べた。

4. 本法に拈ける系統的括よび局所的副作用は軽徽 であり，注入方法・注入薬剤の総量などに十分な考慮 がはらわれるなら，本法は advanced bladder tumor に対する安全かつ有効な治療法であると考光る。

本論文の要旨は日本泌尿器科学会第47回東部連合総会 （1982年, 山形）にて発表した。

\section{文献}

1) Klopp, C.T., Alford, T.C., Bateman, J., Berry, G. N. and Winship, T.: Fractionated intra-arterial cancer chemotherapy with methyl bis amine hydrochloride; A preliminary report. Ann. Surg., 132, 811-832, 1950.

2) Wallace, S., Chuang, V.P., Samuels, M. and Jhnson, D.: Transcatheter intraarterial in- fusion of chemotherapy in advanced bladder cancer. Cancer, 49, 640-645, 1982.

3）松本恵一, 西浦 弘, 垣添忠生: 膀胱癌の化学療 法. 臨泌, 31，135-145，1977.

4）早原信行, 太田崇喜, 堀井明範, 森川洋二, 川村正 喜, 山本啓介, 田中 寛, 安本亮二, 山口哲男, 川 喜多順二, 西島高明, 前田 勉, 松村俊宏, 佐々木 進, 前川正信：末期膀胱癌に対する亜選択的動注 の経験。泌尿紀要， 24，569-575，1978.

5) 斉藤達雄：泌尿器癌に打ける効果判定, 癌化学療 法·癌免疫療法の効果判定基準々制癌剂開発. 第 1 版, 194-201, サイエンスフォーラム, 東京, 1981.

6）服部孝雄，伊藤一二，三輪 潔，平田克治，藤田 浩, 遠藤幸夫：マイトマイシンの術中大量投与. 癌 の臨床, 10, 96-105, 1964.

7）小川秀彌, 平岡保紀, 川井 博：膀胱腫瘍に対する 抗腫湯剂の膀腅腔内注入療法第 5 報 mitomycin C の正常膀胼と膀胼腫瘍とに対する 作用の相違（基礎的・臨床的研究）日泌会誌， 74, 596-607, 1983.

8）小川秀彌，生亀芳雄：堅細胞癌に対する抗癌剤の 動脈内注入療法. 逓信医学, 310-319, 1984.

9）酒本貞昭, 緒方二郎, 前田 浩: 膀脱癌の化学療法 Mitomycin C の内腸骨動脈内持続注入療法と Neocarzinostatin 全身性投与による膀腃癌の治 療. 西日泌尿, 43，223-234，1981.

10) Lang, E.K. Deutsch, J.S. Goodman, J.R., Bernet, T.F., Lanasa, J.A. Jr. and Duplessis, G.H.: Transcatheter embolization of hypogastric branch arteries in the management of intractable bladder hemorrhage. J. Urol., 121, 30-36, 1979.

11) Schuhrke, T.D. and Barr, J.W.: Intractable bladder hemorrhage, Therapeutic angiographic embolization of the hypogastric arteries. J. Urol., 116, 523-530, 1976.

（1985年 1 月 30 日受付） 